\title{
Peroxiredoxin I deficiency increases pancreatic $\beta$-cell apoptosis after streptozotocin stimulation via the AKT/GSK3ß signaling pathway
}

\author{
MEI-HUA JIN $^{1 *}$, GUI-NAN SHEN ${ }^{*}$, YING-HUA JIN ${ }^{2 *}$, HU-NAN SUN $^{1}$, XING ZHEN ${ }^{1}$, YONG-QING ZHANG ${ }^{1}$, \\ DONG-SEOK LEE ${ }^{3}$, YU-DONG CUI ${ }^{1}$, LI-YUN YU ${ }^{1}$, JI-SU KIM ${ }^{4}$, TAEHO KWON ${ }^{4}$ and YING-HAO HAN ${ }^{1}$ \\ ${ }^{1}$ Laboratory of Disease Model Research Center, College of Life Science and Biotechnology, \\ Heilongjiang Bayi Agricultural University; ${ }^{2}$ Department of Library and Information Center, \\ Library of Heilongjiang Bayi Agricultural University, Daqing, Heilongjiang 163319, P.R. China; \\ ${ }^{3}$ School of Life Sciences, KUN Creative Bioresearch Group, Kyungpook National University, \\ Daegu, Gyeongsangbuk 702-701; ${ }^{4}$ Primate Resources Center, Korea Research Institute of Bioscience \\ and Biotechnology, Ibam-myeon, Jeongeup-si, Jeonbuk 56216, Republic of Korea
}

Received January 8, 2020; Accepted May 28, 2020

DOI: $10.3892 / \mathrm{mmr} .2020 .11279$

\begin{abstract}
Apoptosis of pancreatic $\beta$-cells is involved in the pathogenesis of type I and II diabetes. Peroxiredoxin I (Prx I) serves an important role in regulating cellular apoptosis; however, the role of Prx I in pancreatic $\beta$-cell apoptosis is not completely understood. In the present study, the role of peroxiredoxin 1 (Prx I) during streptozotocin (STZ)-induced apoptosis of pancreatic $\beta$-cells was investigated. The expression level of Prx I was decreased by STZ treatment in a time-dependent manner, and apoptosis of Prx I knockdown MIN6 cells was increased by STZ stimulation, compared with untransduced MIN6 cells. Furthermore, an intraperitoneal injection of STZ increased pancreatic islet damage in Prx I knockout mice, compared with wild-type and Prx II knockout mice. AKT and glycogen synthase kinase (GSK)-3 $\beta$ phosphorylation significantly decreased following Prx I knockdown in MIN6 cells. However, phosphorylated $\beta$-catenin and p65 levels significantly increased after STZ stimulation, compared with untransduced
\end{abstract}

Correspondence to: Dr Taeho Kwon, Primate Resources Center, Korea Research Institute of Bioscience and Biotechnology, 351-33 Neongme-gil, Ibam-myeon, Jeongeup-si, Jeonbuk 56216, Republic of Korea

E-mail: kwon@kribb.re.kr

Dr Ying-Hao Han, Laboratory of Disease Model Research Center, College of Life Science and Biotechnology, Heilongjiang Bayi Agricultural University, 2 Xingyanglu, Daqing, Heilongjiang 163319, P.R. China

E-mail: hyhbynd@163.com

${ }^{*}$ Contributed equally

Key words: peroxiredoxin I, apoptosis, streptozotocin, $\beta$-cell, glycogen synthase kinase- $3 \beta$ signaling cells. The results of the present study indicate that deletion of Prx I mediated STZ-induced pancreatic $\beta$-cell death in vivo and in vitro by regulating the AKT/GSK-3 $\beta / \beta$-catenin signaling pathway, as well as NF- $\mathrm{NB}$ signaling. These findings provide a theoretical basis for treatment of pancreatic damage.

\section{Introduction}

Diabetes is a disease that often manifests as hyperglycemia and is caused both by genetic and environmental factors. Diabetes is classified into type I and type II diabetes. Type I diabetes is an autoimmune disease mediated by $\mathrm{T}$ lymphocytes, characterized by inflammation and selective damage to pancreatic $\beta$-cells, resulting in severe insulin deficiency $(1,2)$. Type II diabetes is characterized by chronic hyperglycemia and insulin resistance caused by reduced sensitivity of liver, muscle and adipose tissue to insulin (3).

An abnormal pancreatic $\beta$-cell count is a key factor in the pathogenesis of type I and type II diabetes (4). Indeed, the advanced stage of type I diabetes presents severe loss and elimination of pancreatic $\beta$-cells (5). Moreover, previous studies reported that the pancreatic $\beta$-cell count was significantly reduced in patients with type II diabetes $(6,7)$. Thus, the regulation of pancreatic $\beta$-cell proliferation, apoptosis and regeneration affects the progression of diabetes $(8,9)$.

Apoptosis and proliferation of pancreatic $\beta$-cells are essential to the maintenance of the blood glucose balance $(10,11)$. In type I diabetes, infiltrating immune cells produce several cytokines, such as interleukin-1 $\beta$, interferon- $\gamma$ and tumor necrosis factor- $\alpha$. Pro-inflammatory cytokines activate signaling cascades, such as $\mathrm{NF}-\kappa \mathrm{B}$ signaling, that result in increased production of nitric oxide, causing endoplasmic reticulum stress-induced pancreatic $\beta$-cell apoptosis $(12,13)$. Furthermore, increased cytokine levels can also activate the JNK/p38 and STAT1 signaling pathways, which promote mitochondria-dependent cell apoptosis by downregulating Bcl-2 expression, which is essential for cytochrome $c$ release, ultimately inducing $\beta$-cell apoptosis (14-16). 
Streptozotocin (STZ) is often used to establish hyperglycemia in animal models (17). STZ enters pancreatic $\beta$-cells through the glucose transporter GLUT2 and induces the production of reactive oxygen species (ROS), which, in turn, damages DNA and leads to pancreatic $\beta$-cell apoptosis $(17,18)$. Previous studies reported that STZ treatment significantly increased the levels of intracellular ROS, Bax and cleaved-caspase-9 and -3 in MIN6 cells, thereby enhancing apoptosis (19-21). Thus, STZ stimulates $\beta$-cell apoptosis in vitro.

Peroxiredoxins (Prxs) are crucial in maintaining the balance of the redox system by maintaining intracellular $\mathrm{H}_{2} \mathrm{O}_{2}$ homeostasis via their peroxidase activity to decrease ROS redox reactions in cells. Prx I regulates antioxidant and oxidation-sensitive signal transduction (22). A previous study reported that the expression of Prx family members was altered under various pathological conditions, such as cancer and diabetes (23). In response to cytokine stimulation, both Prx I and Prx II expression levels are upregulated in pancreatic $\beta$-cells, which suggests a possible involvement of Prx I and Prx II in the progression of type I diabetes. Furthermore, it has been reported that Prx I is more sensitive to cytokine stimulation than Prx II (24). Patients with type II diabetes present higher plasma levels of Prx I, compared with healthy individuals, which was reported as an indicator of glycemic control in type II diabetes (25). Pancreatic $\beta$-cell apoptosis and function decline have been implicated not only in type I and type II diabetes, but also in pancreatic transplantation (26).

In the present study, the role of Prx I in the progression of type I diabetes was examined. The potential regulatory function of Prx I in STZ-induced pancreatic $\beta$-cell apoptosis was investigated both in vivo and in vitro, using Prx I knockout mice and MIN6 pancreatic cells.

\section{Materials and methods}

Animals. Male, 8-week-old wild-type, $\operatorname{Prx} \mathrm{I}^{-/-}$and $\operatorname{Prx} \mathrm{II}^{-/-}$mice (129/SvJ strain; $n=6$ in each group; Korea Research Institute of Bioscience and Biotechnology) weighing 22-25 g were used in the present study. All mice were maintained in a pathogen-free facility at $20-22^{\circ} \mathrm{C}$, with $50-60 \%$ humidity and a 12 -h-dark/light cycle, and had free access to food and water. Mice received $50 \mathrm{mg} / \mathrm{kg}$ STZ by intraperitoneal injection $(17,21,27,28)$ once daily for five consecutive days to establish a type I diabetes mice model. Mice were sacrificed by cervical dislocation under deep anesthesia and the pancreas were sampled on day $7(17,18,21,29)$. All experiments were approved by The Institutional Animal Care and Use Committee.

Cell culture. MIN6 cells were obtained from Shanghai Bogoo Biological Technology Co., Ltd., and were maintained in Dulbecco's modified Eagle medium (Gibco; Thermo Fisher Scientific, Inc.) supplemented with $10 \%$ heat inactivated FBS (Beijing Solarbio Science \& Technology Co., Ltd.), 2 mM L-glutamine, $100 \mathrm{U} / \mathrm{ml}$ penicillin and streptomycin (Beijing Solarbio Science \& Technology Co., Ltd.) at $37^{\circ} \mathrm{C}$ in a $5 \% \mathrm{CO}_{2}$ humidified incubator. MIN6 cells were seeded in a 6-well plate at a density of $3 \times 10^{5}$ cells/well and cultured to $80-90 \%$ confluence. Cells were stimulated with $5 \mu \mathrm{M}$ STZ (Biosharp Life Sciences) for another $24 \mathrm{~h}$ at $37^{\circ} \mathrm{C}$.
Establishment of Prx I-knockdown stable cell line. For the construction of lentivirus packaging Prx I short hairpin (sh)RNA, control scrambled shRNA (5'-TTCTCCGAACGT GTCACGTTTC-3') and shRNAs specifically targeting Prx I (5'-CAGTGATAGAGCCGAT-3') were synthesized and inserted into the pGLV3/H1/GFP+Puro lentiviral vector (Shanghai GenePharma Co., Ltd.) (26). Prior to viral infection, MIN6 cells were seeded in 6-wells plate at the density of $3 \times 10^{5}$ cells/well and cultured to $70-80 \%$ confluence. Lentiviral particles were produced by transfecting $293 \mathrm{~T}$ cells (30-40\% confluence) with the $0.5 \mu \mathrm{g} / \mathrm{ml}$ expression plasmids and $1.5 \mu \mathrm{g} / \mathrm{ml}$ packaging vectors (pGag/Pol, pRev; pVSV-G; Shanghai GenePharma Co., Ltd.) using the RNAi-mate transfection reagent (Shanghai GenePharma Co., Ltd.), following the manufacturer's protocol. After 72-h transfection, the supernatant containing lentiviral particles was collected and centrifuged at $1,500 \mathrm{x} \mathrm{g}$ for $4 \mathrm{~min}$ at $4^{\circ} \mathrm{C}$, then filtered with $0.45-\mu \mathrm{m}$ cellulose acetate filters to eliminate cell debris. Lentiviral supernatants were then ultra-centrifuged at $48,400 \mathrm{x} \mathrm{g}$ for $2 \mathrm{~h}$ at $4^{\circ} \mathrm{C}$. Viral stock containing shPrx I at a multiplicity of infection of 100 was added along with $5 \mu \mathrm{g} / \mathrm{ml}$ of polybrene (Shanghai GenePharma Co., Ltd.) to the MIN6 cells. After $24 \mathrm{~h}$, cells were inoculated in fresh culture media. Transduced MIN6 cells were incubated in 10\% FBS DMEM containing $2 \mu \mathrm{g} / \mathrm{ml}$ puromycin for selection at $37^{\circ} \mathrm{C}$ in a $5 \% \mathrm{CO}_{2}$ humidified incubator. After two rounds of selection, transduced MIN6 cells were incubated in 10\% FBS DMEM without puromycin for $24 \mathrm{~h}$ and transduction efficiency was confirmed by flow cytometry and western blot analysis.

FGF2 treatment. Transduced MIN6 cells were cultured $\left(3 \times 10^{5}\right.$ cells/well) in a 6 -well plate. At $80-90 \%$ confluence, cells were treated with $20 \mathrm{ng} / \mathrm{ml} \mathrm{FGF2} \mathrm{(GenScript)} \mathrm{for} 2 \mathrm{~h}$ at $37^{\circ} \mathrm{C}$, followed by $5 \mu \mathrm{M} \mathrm{STZ}$ treatment for $24 \mathrm{~h}$ at $37^{\circ} \mathrm{C}$.

Flow cytometry. MIN6 cells transduced with shRNA vectors expressing GFP were cultured in DMEM containing $10 \% \mathrm{FBS}$ and $2 \mu \mathrm{g} / \mathrm{ml}$ puromycin for selection. After selection, $1 \times 10^{6}$ cells were harvested and added to individual tubes. Data were acquired on a CytoFLEX flow cytometer and GFP expression was analyzed using the CytExpertsoftware (version 1.2.10.0, both from Beckman Coulter, Inc.).

Annexin $V$ staining. MIN6 cells were cultured for $24 \mathrm{~h}$ in 6 -well plates at a concentration of $4 \times 10^{5}$ cells/well. Cells were then treated with $5 \mathrm{mM}$ STZ for the indicated times $(0,12$ or $24 \mathrm{~h}$ ) at $37^{\circ} \mathrm{C}$ in a $5 \% \mathrm{CO}_{2}$ humidified incubator. After treatment, cells were washed with PBS, then incubated with $1 \mu \mathrm{l}$ Annexin V-phycoerythrin in $199 \mu \mathrm{l}$ cell binding buffer for $15 \mathrm{~min}$ at room temperature. After staining, the cells were washed twice with PBS, then analyzed under a DM2500 fluorescence microscope (Leica Microsystems GmbH; magnification, x100).

Western blot analysis. Total protein was extracted using ice-cold cell extraction buffer [20 mM HEPES (pH 7.0), $50 \mathrm{mM}$ $\mathrm{NaCl}, 10 \%$ Triton $\mathrm{X}-100,10 \%$ glycerol, $1 \mathrm{mM} \beta-\mathrm{ME}$, protease inhibitor cocktail tablet] for $30 \mathrm{~min}$. Lysates were centrifuged at $13,200 \mathrm{x} \mathrm{g}$ at $4^{\circ} \mathrm{C}$ for $20 \mathrm{~min}$. Total protein $(2 \mu \mathrm{g} / \mu \mathrm{l})$ was quantified using the Bradford assay. Proteins $(2 \mu \mathrm{g} / \mu \mathrm{l})$ were separated 
A

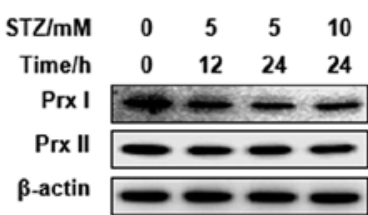

B



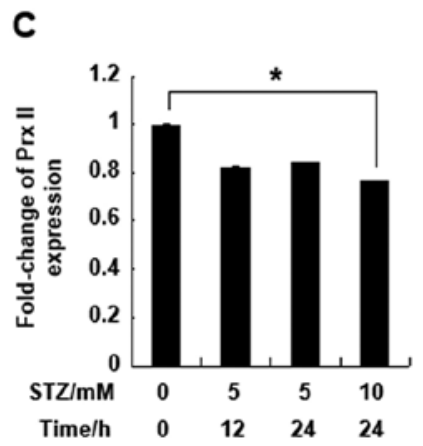

D

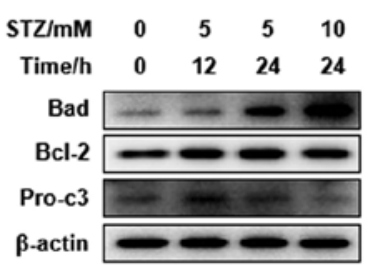

E



$\mathbf{F}$



G

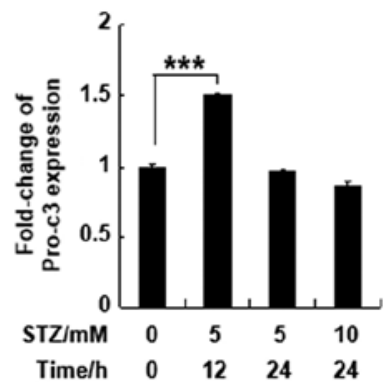

Figure 1. STZ regulates the expression of Prx I and apoptosis-related proteins in the MIN6 cell line. (A) Protein expression of Prx I and Prx II after STZ treatment was evaluated by western blotting in MIN6 cells. (B and C) Relative protein expression levels of Prx I and II. (D) Expression of apoptosis-related proteins Bad, Bcl-2 and pro-c3 were evaluated by western blotting. (E-G) Relative protein expression levels of Bad, Bcl-2 and pro-c3. Data are presented as the mean \pm SD. $n=6$. ${ }^{*} \mathrm{P}<0.05,{ }^{* *} \mathrm{P}<0.01$ and ${ }^{* * *} \mathrm{P}<0.001$. STZ, streptozotocin; Prx, peroxiredoxin; pro-c3, pro-caspase-3.

via $12 \%$ SDS-PAGE and transferred to a nitrocellulose filter membrane (EMD Millipore). After incubation in 5\% skimmed milk blocking solution at room temperature for $1 \mathrm{~h}$, the membrane was probed overnight at $4^{\circ} \mathrm{C}$ using primary antibodies. The blots were then incubated with anti-Prx I (1:2,000; cat.no. sc-7381), Prx II (1:2,000; cat.no. sc-515429), Bad (1:2,000; cat. no. sc-8044), Bcl-2 (1:2,000; cat. no. sc-7382), pro-caspase-3 (1:2,000; cat. no. sc-373730), AKT (1:2,000; cat. no. sc-8312), phosphorylated (p)-AKT (1:2,000; cat. no. sc-7985-R), glycogen synthase kinase(GSK)-3 $\beta$ (1:2,000; cat. no. sc-377213),p-GSK3 $\beta$ (1:2,000; cat. no. sc-81496), $\beta$-catenin (1:2,000; cat. no. sc-7963), p- $\beta$-catenin $(1: 2,000$; cat. no. sc-57533), inhibitor of nuclear factor- $\kappa \mathrm{B} \alpha$ (IкB- $\alpha$; 1:2,000; cat. no. sc-1643), p-p65 (1:2,000; cat. no. sc-166748) and $\beta$-actin $(1: 2,000$; cat. no. sc-47778) antibodies. The membranes were washed five times with TBST (0.2\% Tween-20) and incubated for $1 \mathrm{~h}$ at room temperature with horseradish peroxidase-conjugated secondary antibodies (1:5,000; cat. nos. sc-2004 and sc-2005). All antibodies were purchased from Santa Cruz Biotechnology, Inc. After washing with TBST, the blots were developed using a chemiluminescence detection system (GE Healthcare). Band intensities were quantified using the ImageJ software. (version 1.52a; National Institutes of Health).

Hematoxylin and eosin $(H \& E)$ staining. Pancreatic tissues were fixed in $4 \%$ paraformaldehyde overnight at room temperature, then embedded in paraffin. Tissues were cut into $5-\mu \mathrm{m}$ sections for H\&E staining. Following which, samples were maintained in xylene solution for $20 \mathrm{~min}, 100 \%$ alcohol for $1.5 \mathrm{~min}, 90 \%$ alcohol for $1 \mathrm{~min}, 80 \%$ alcohol for $1 \mathrm{~min}$, then $50 \%$ alcohol for $1 \mathrm{~min}$. The sections were stained with hematoxylin solution for $5 \mathrm{~min}$ at room temperature, then treated by acid-alcohol and $0.8 \%$ ammonia for $2 \mathrm{sec}$. The sections were then stained with eosin solution for $20 \mathrm{sec}$, 95\% alcohol for $1 \mathrm{~min}, 100 \%$ alcohol for $1 \mathrm{~min}$, xylene for $1 \mathrm{~min}$, then sealed in neutral gum. The sections were examined under a DM2500 fluorescence microscope (Leica Microsystems GmbH; magnification, x200).

Statistical analysis. Statistical analysis was carried out using two-way ANOVA to analyze the changes across time and differences between groups, followed by Tukey's post hoc test $(\alpha=0.05) . P<0.05$ was considered to indicate a statistically significant difference. Statistical analyses were conducted using SPSS software (version 25; IBM Corp). Experiments were performed in duplicate and were repeated at least three times.

\section{Results}

STZ treatment downregulates Prx I expression and upregulates the expression of apoptosis-related proteins in MIN6 cells. To understand the effect of STZ treatment on Prx I and Prx II protein expression levels, MIN6 pancreatic cells were treated with 5 or $10 \mathrm{mM} \mathrm{STZ} \mathrm{for} 12$ or $24 \mathrm{~h}$. STZ significantly downregulated expression levels of Prx I after 12 or $24 \mathrm{~h}$ of treatment. However, Prx II protein expression in MIN6 cells was not affected by STZ, except at a higher concentration and following longer incubation times (10 mM for $24 \mathrm{~h}$; Fig. 1A-C). Bad and Bcl-2 protein expression levels were significantly upregulated at all concentrations and time points compared with the control group. Pro-caspase-3 protein expression was 
A
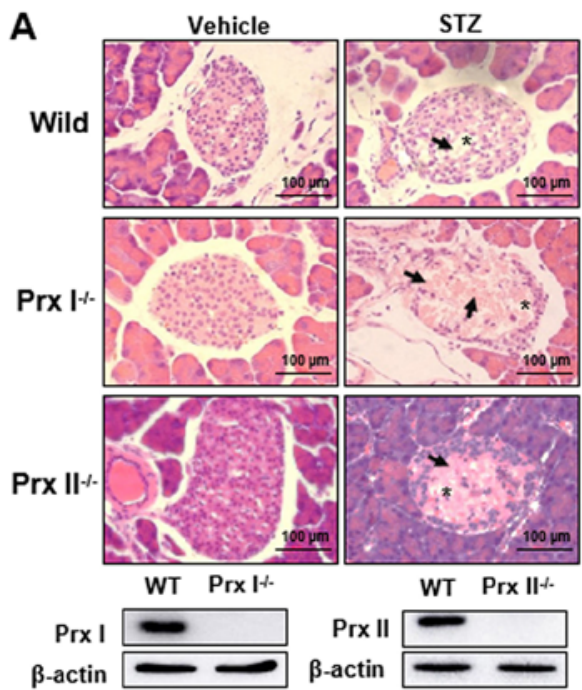

D

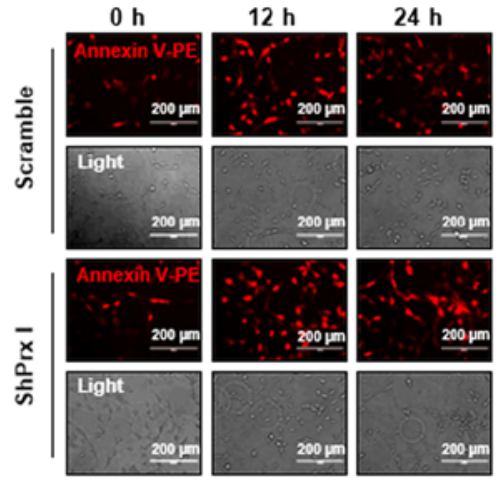

B

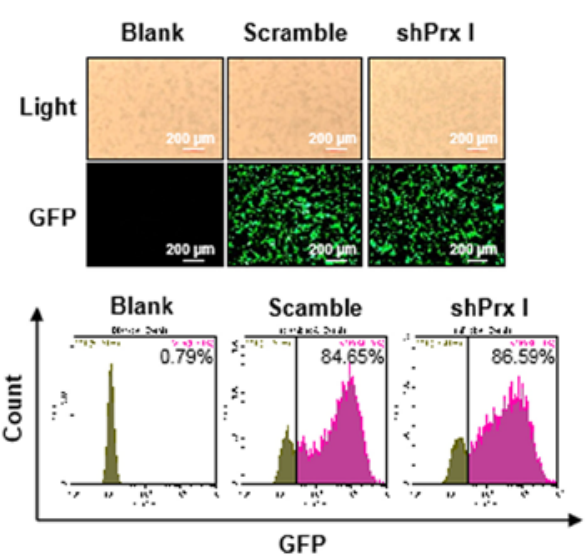

C

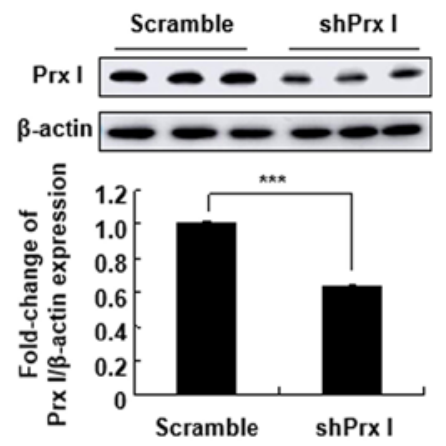

E
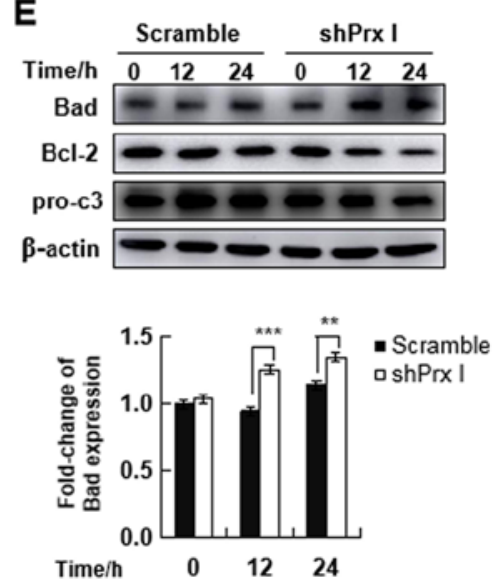
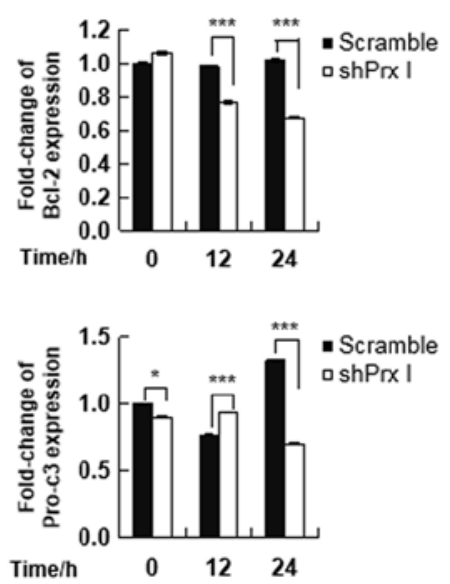

Figure 2. Prx I knockdown increases apoptosis of pancreatic $\beta$-cells. (A) Hematoxylin-eosin staining analysis of pancreatic islets after STZ injection in wild-type, Prx I/- and Prx II ${ }^{-/-}$mice. STZ-treated mice displayed degeneration and shrinkage of Islets of Langerhans, illustrated by Islet amyloidosis with atrophied Islets $\beta$-cells (arrows). *Indicates cytoplasmic vacuoles. Mouse genotype was confirmed by western blotting. Scale bar, $100 \mu \mathrm{m}$. (B) GFP expression was detected by immunofluorescence (upper panel) and flow cytometry (lower panel) blank, scramble, and shPrx I MIN6 cell lines. (C) Expression levels of Prx I in scramble and shPrx I-transduced MIN6 cells. (D) Apoptosis was analyzed by Annexin V-PE staining and observed using fluorescence microscopy after STZ treatment in both scramble and shPrx I-transduced MIN6 cells. (E) Bad, Bcl-2 and pro-c3 expression levels were evaluated by western blot analysis in scramble and shPrx I-transduced MIN6 cells following STZ treatment. Data are presented as the mean $\pm \mathrm{SD} . \mathrm{n}=6$ in each group. ${ }^{*} \mathrm{P}<0.05$, ${ }^{* *} \mathrm{P}<0.01$ and ${ }^{* * *} \mathrm{P}<0.001$. STZ, streptozotocin; Prx, peroxiredoxin; pro-c3, pro-caspase-3; GFP, green fluorescent protein; PE, phycoerythrin; WT, wild-type; shRNA; short hairpin RNA.

also upregulated following incubation with $5 \mathrm{mM} \mathrm{STZ} \mathrm{for}$ $12 \mathrm{~h}$ compared with the control group (Fig. 1D-G). The results indicated that Prx I was more sensitive to STZ treatment compared with Prx II.

Prx I knockdown increases STZ-induced $\beta$-cell death in vivo and in vitro. To understand the effect of Prx I and Prx II deletion on acute pancreatic damage in vivo, wild-type, $\operatorname{Prx~I} \mathrm{I}^{-/}$and $\operatorname{Prx~} \mathrm{II}^{-/-}$mice were injected with $50 \mathrm{mg} / \mathrm{kg} \mathrm{STZ}$ according to the aforementioned protocol. After treatment the mice were sacrificed, and pancreatic damage was examined with H\&E staining. Degeneration and shrinkage of pancreatic islet tissue was observed in Prx I knockout mice after STZ treatment compared with the wild- and Prx II knockout mice, suggesting that Prx I is essential for protecting the pancreas islands against STZ stimulation (Fig. 2A).

To understand the regulatory function of Prx I in pancreatic $\beta$-cells, MIN6 pancreatic cells were transduced with Prx I knockdown constructs. A scramble vector was used as a control. Transduction efficiency was quantified by GFP expression using fluorescence microscopy and flow cytometry (Fig. 2B). Based on GFP expression, transduction efficiency was estimated to be 84.65 and $86.59 \%$ with scramble and shPrx I, respectively (Fig. 2B). Transfection efficiency was confirmed using western blotting, which showed that Prx I expression was significantly reduced in shPrx I-transduced cells, compared with cells transduced with the scramble control (Fig. 2C).

To investigate whether STZ-mediated cell death was detectable following Prx I knockdown, scramble and shPrx I transduced MIN6 cells were treated with $5 \mathrm{mM}$ STZ for 12 or $24 \mathrm{~h}$. Examination of Annexin V staining by fluorescence microscopy indicated that STZ-induced cell apoptosis was increased in the shPrx I-transduced MIN6 cells, compared with scramble cells (Fig. 2D). The expression of apoptosis-related proteins was also examined following STZ treatment (Fig. 2E). STZ significantly upregulated the expression of the proapoptotic protein $\mathrm{Bad}$ in shPrx I-transduced cells, compared with scramble cells. However, expression of $\mathrm{Bcl}-2$, which is an anti-apoptotic protein, was significantly downregulated. The expression 
A

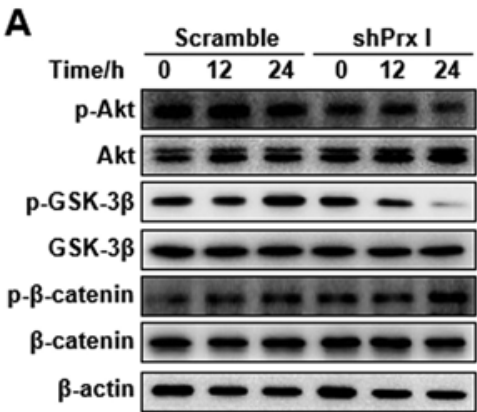

E

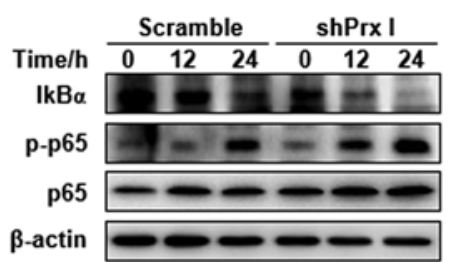

B

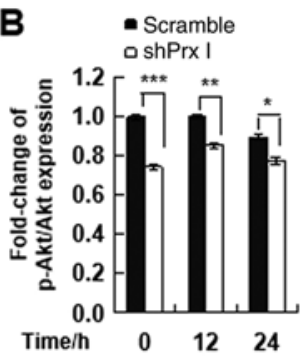

C

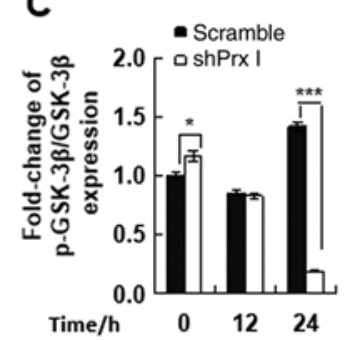

D

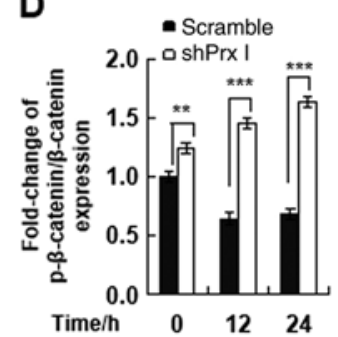

$\mathbf{F}$

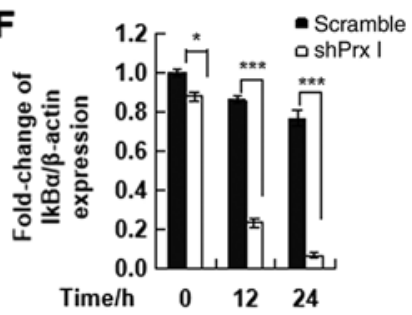

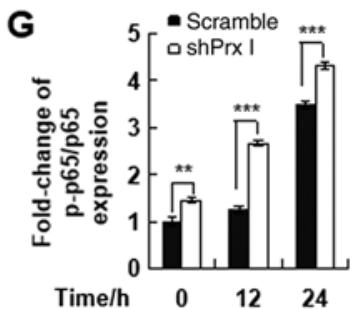

Figure 3. Effect of Prx I knockdown on the AKT/GSK-3 $\beta / \beta$-catenin and NF- $\kappa$ B signaling pathways. (A) Western blot analysis of p-AKT, AKT, p-GSK3 $\beta$, $\mathrm{p}-\beta$-catenin and $\beta$-catenin protein expression in scramble and shPrx I-transduced MIN6 cells following STZ stimulation. (B-D) Relative protein expression levels p-AKT, p-GSK3 $\beta$, and p- $\beta$-catenin. (E) Western blot analysis of I $\kappa \mathrm{B} \alpha$ and p-p65 protein expression in scramble and shPrx I-transduced MIN6 cells following STZ stimulation. ( $\mathrm{F}$ and $\mathrm{G}$ ) Relative protein expression levels of $\mathrm{I} \kappa \mathrm{B} \alpha$ and p-p65. Data are presented as the mean $\pm \mathrm{SD}$. ${ }^{*} \mathrm{P}<0.05$, ${ }^{* *} \mathrm{P}<0.01$ and ${ }^{* * *} \mathrm{P}<0.001$. STZ, streptozotocin; Prx, peroxiredoxin; GSK-3 $\beta$, glycogen synthase kinase-3 $\beta$; I $\mathrm{B} \alpha$, inhibitor of nuclear factor- $\kappa \mathrm{B} \alpha$; $\mathrm{p}$, phosphorylated; shRNA; short hairpin RNA.

of pro-caspase-3 was also significantly downregulated after 24-h STZ treatment.

Prx I knockdown upregulates the AKT/GSK3 $\beta / \beta$-catenin and $N F-\kappa B$ signaling pathways. To understand the possible molecular mechanism underlying the effects of Prx I on STZ-induced pancreatic $\beta$-cell apoptosis, activation of the AKT/GSK3 $\beta / \beta$-catenin and NF- $\kappa \mathrm{B}$ signaling pathways in shPrx I-transduced cells following 12 or 24-h STZ treatment were assessed. The expression levels of p-AKT and p-GSK3 $\beta$ were significantly reduced in shPrx I-transduced cells, compared with scramble. By contrast, $\beta$-catenin phosphorylation was significantly upregulated following Prx I knockdown and STZ treatment (Fig. 3A-D).

Moreover, to verify the effect of Prx I on STZ-induced NF- $\kappa$ B signaling activation, scramble and Prx I-knockdown MIN6 cells were treated with STZ for the indicated times. STZ treatment significantly reduced the expression levels of I $\mathrm{B} \alpha$, which may suggest increased degradation of $\mathrm{I} \kappa \mathrm{B} \alpha$, compared with scramble cells. In addition, p65 phosphorylation was significantly increased in shPrx I-transduced cells, compared with scramble (Fig. 3E-G).

FGF2 treatment reverses STZ-induced MIN6 cell apoptosis in Prx I-knockdown MIN6 cells. To the best of the authors' knowledge, FGF2 can efficiently activate the AKT signaling pathways (30). Thus, to understand the regulatory role of Prx I on the AKT signaling pathway following STZ stimulation, shPrx I-transduced MIN6 cells were pre-treated with FGF2 for $2 \mathrm{~h}$, followed by STZ treatment for $24 \mathrm{~h}$. Pre-treatment with FGF2 reduced STZ-induced cellular apoptosis in shPrx I-transduced cells, compared with scramble (Fig. 4A). Furthermore, FGF2 also reversed the effects STZ, Bad expression decreased following treatment with FGF2, whereas Bcl-2 and pro-caspase-3 expression increased compared with STZ treatment alone (Fig. 4B-E).

\section{Discussion}

Streptozotocin was originally isolated from Streptomyces achromogenes, and has been used as an antibiotic and anticancer drug. Presently, STZ is more commonly used in drug therapy for rare neuroendocrine tumors (31). STZ can induce diabetes in experimental animals by intravenous or intraperitoneal injection and is widely used in the study of diabetes (32). STZ is taken up by cells through the GLUT2 glucose transporter, and has a selective destructive effect on pancreatic $\beta$-cells (33). In animal models, high doses of STZ leads to extensive destruction of pancreatic $\beta$-cells, thereby increasing blood glucose levels and urine output, thus replicating the characteristics of type I diabetes (34). However, multiple small doses of STZ in combination with a high-fat diet partly destroy pancreatic cell function, and as peripheral tissues become insensitive to insulin; the observed pathological changes are closer to those of type II diabetes (29). Pancreatic $\beta$-cell injury is key in the development and progression of diabetes, and damage to the pancreatic $\beta$-cells results in reduced insulin secretion, thereby accelerating the development of diabetes (35). STZ induces pancreatic $\beta$-cell apoptosis mainly through ROS, reactive nitrogen species and DNA damage (36). Moreover, pancreatic $\beta$-cells are highly sensitive to ROS-mediated damage, which can directly induce cell apoptosis (37). Additionally, ROS can also indirectly damage the pancreatic $\beta$-cell via the signaling pathways that affect insulin synthesis and secretion (38).

As STZ induces diabetes by increasing the production of ROS and inhibiting the oxidative stress defense system (39), understanding the relationship between antioxidant defense 
A

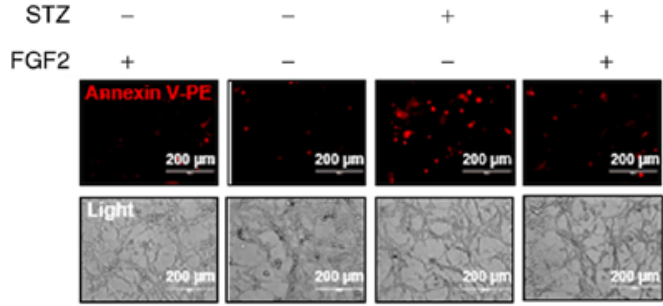

B

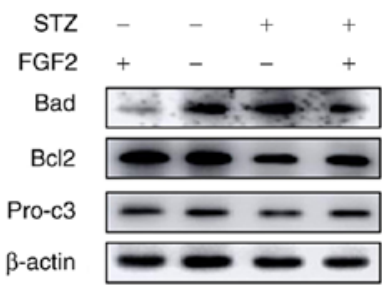

C

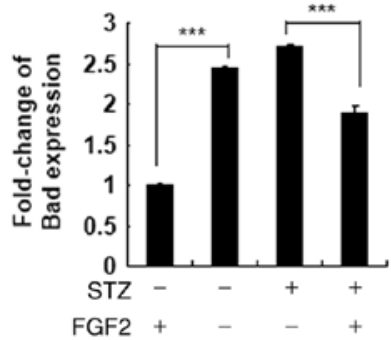

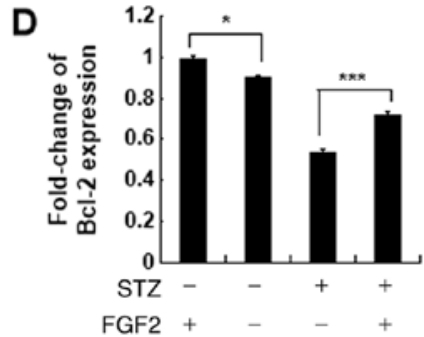

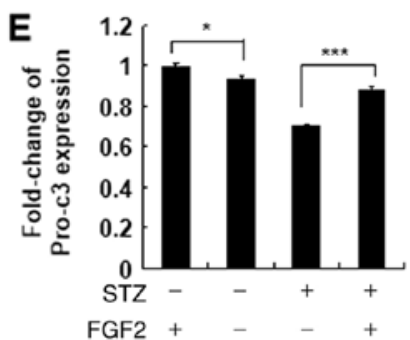

Figure 4. Effect of FGF2 treatment on STZ-induced cell apoptosis in shPrx I-transduced MIN6 cells. (A) shPrx I MIN6 cells were pretreated with $20 \mu$ M FGF2 for $30 \mathrm{~min}$ followed by STZ treatment. Apoptosis was analyzed by Annexin V-PE staining and observed with fluorescence microscopy. Scale bar, $100 \mu \mathrm{m}$. (B) Western blot analysis of Bad, Bcl-2 and pro-c3 expression in shPrx I-transduced MIN6 cells after FGF2 and STZ treatment. (C-E) Relative protein expression levels of Bad, Bcl-2 and pro-c3. Data are presented as the mean $\pm \mathrm{SD}$. " $\mathrm{P}<0.05$ and ${ }^{* * * *} \mathrm{P}<0.001$. STZ, streptozotocin; Prx, peroxiredoxin; FGF2, fibroblast growth factor-2; PE, phycoerythrin; shRNA, short hairpin RNA; pro-c3, pro-caspase-3.

systems and ROS-induced pancreatic $\beta$-cell injury would provide invaluable insight into the pathogenesis of diabetes. In the present study, treatment with STZ significantly downregulated Prx I, but not Prx II, and altered the expression levels of apoptotic proteins, suggesting a possible involvement of Prx I in STZ-induced $\beta$-cell apoptosis.

Peroxiredoxins represent a large and highly conserved family of peroxidases, which reduce peroxides with a conserved cysteine residue (40). It has been reported that Prx VI-knockout mice have impaired insulin signaling, which leads to reduced muscle glucose uptake (41). Prx III protects pancreatic $\beta$-cells from stress-related apoptosis (42). Moreover, Prx II also exhibits a protective role in pancreatic $\beta$-cells under oxidative stress (43). Collectively, these previous studies indicate that members of the Prx family may play a pivotal role in the development of diabetes. The results of present study suggested that both $\operatorname{Prx~\mathrm {I}^{-/}}$ and $\operatorname{Prx} \mathrm{II}^{--}$mice pancreatic $\beta$-cells were destroyed following STZ treatment. This result demonstrated that both Prx I and Prx II may protect pancreatic $\beta$-cells from STZ-induced cell apoptosis. Notably, Prx I was more sensitive to STZ stimulation. Sensitivity of Prx I to other compounds has also been reported in related studies. For instance, treatment of INS-1E $\beta$-cells with oleate and palmitate resulted in a significant increase in Prx I expression $(44,45)$. In the present study, the protective role of Prx I was also confirmed by silencing Prx I expression with lentivirus vectors in the MIN6 cell line. Therefore, Prx I may play a pivotal role in protecting pancreatic $\beta$-cells against STZ-induced cell apoptosis.

The AKT signaling pathway is crucial in regulating the proliferation and apoptosis of pancreatic $\beta$-cells. Activated AKT can phosphorylate substrates for various biological processes, thus regulating insulin-mediated glucose transport, protein and glycogen synthesis, as well as cell proliferation, differentiation and survival (46-48). It was previously demonstrated that Akt2-deficient mice present mild glucose intolerance and insulin resistance, and some of them developed diabetes (49). A previous study also reported that AKT could promote cell survival (50). AKT-mediated phosphorylation of GSK-3 and forkhead transcription factors (including forkhead box O1) may also promote cell survival via downstream targets (51). For example, AKT-mediated inactivation of GSK-3 reduces GSK-3-mediated phosphorylation of $\beta$-catenin, leading to increased cell survival (52). In some cell types, $\beta$-catenin can be transferred from the cytosol to the nucleus after phosphorylation of GSK-3. GSK-3-mediated phosphorylation of $\beta$-catenin promotes its degradation. In various cancer cells, decreased phosphorylation of GSK3- $\beta$ (ser9) leads to reduced $\mathrm{Bcl}-2 / \mathrm{Bcl}-\mathrm{xL}$ expression and elevated expression of Bax/Bad, which regulate apoptosis $(40,53,54)$. Phosphorylated AKT can inhibit the phosphorylation GSK3- $\beta$ (ser21) and GSK3- $\beta$ (ser9), and inhibit their activity (54). The present study demonstrated that the expression of p-AKT and p-GSK3- $\beta$ (ser9) was significantly decreased in Prx I-knockdown MIN6 cells after STZ treatment. Notably, the addition of FGF2, which can upregulate the AKT signaling pathway, significantly inhibited STZ-induced cell apoptosis in Prx I-knockdown MIN6 cells, and reversed the effects of STZ on apoptosis-related protein expression. These results indicate that the AKT signaling pathway may be an important signaling pathway that is stimulated by STZ in $\beta$-cell apoptosis, and the function of Prx I on regulating STZ-induced cell death may also occur via the same mechanism. Nevertheless, the possible regulatory mechanism of Prx I on STZ-induced $\beta$-cell apoptosis requires further study, and future studies should investigate the regulatory mechanisms affecting the NF- $\kappa \mathrm{B}$ signaling pathway, mitochondrial function and cellular ROS-related pathways. Furthermore, such study should extend to both type I and type II diabetes pathogenesis.

In summary, deletion of Prx I increased STZ-induced pancreatic $\beta$-cell apoptosis in MIN6 cells, and exacerbated STZ-induced pancreatic damage in vivo. The increase in apoptosis as a result of Prx I knockdown may occur via the AKT/GSK $/ \beta$-catenin and NF- $\kappa B$ signaling pathways. The 
present findings provide a novel insight for treatment of pancreatic damage caused by oxidative stress.

\section{Acknowledgements}

Not applicable.

\section{Funding}

The present study was supported by the Basic Science Research Program through the National Research Foundation of Korea funded by the Ministry of Education (grant no. 2020R1I1A2052417), the Korean Research Institute of Bioscience and Biotechnology Research Initiative Program (grant no. KGM5162021), the Research Project of Heilongjiang Bayi Agricultural University (grant no. XYB2013-17) and the Natural Science Foundation of Heilongjiang Province of China (grant no. QC2015121).

\section{Availability of data and materials}

The datasets used and/or analyzed during the current study are available from the corresponding author on reasonable request.

\section{Authors' contributions}

MHJ, GNS and YHJ constructed the disease model, designed the study and wrote the manuscript. HNS, XZ and YQZ performed the experiments. DSL, JSK, YDC and LYY performed carried out data analysis. TK and YHH made substantial contributions to conception and design. All authors read and approved the final manuscript.

\section{Ethics approval and consent to participate}

All procedures were approved by the Heilongjiang Bayi Agricultural University Animal Care and Use Committee and conformed to the National Institutes of Health Guide for the Care and Use of Animals in Research.

\section{Patient consent for publication}

Not applicable.

\section{Competing interests}

The authors declare that they have no competing interests.

\section{References}

1. Lincez PJ, Shanina I and Horwitz MS: Reduced expression of the MDA5 gene IFIH1 prevents autoimmune diabetes. Diabetes 64: 2184-2193, 2015.

2. Taborsky GJ Jr, Mei Q, Hackney DJ and Mundinger TO: The search for the mechanism of early sympathetic islet neuropathy in autoimmune diabetes. Diabetes Obes Metab 16 (Suppl 1): S96-S101, 2014.

3. Yang ZH, Miyahara H and Hatanaka A: Chronic administration of palmitoleic acid reduces insulin resistance and hepatic lipid accumulation in KK-A y Mice with genetic type 2 diabetes. Lipids Health Dis 10: 120, 2011.

4. Guo T and Hebrok M: Stem cells to pancreatic beta-cells: New sources for diabetes cell therapy. Endocr Rev 30: 214-227, 2009.
5. Ilonen J, Lempainen J and Veijola R: The heterogeneous pathogenesis of type 1 diabetes mellitus. Nat Rev Endocrinol 15: 635-650, 2019.

6. Spijker HS, Song H, Ellenbroek JH, Roefs MM, Engelse MA, Bos E, Koster AJ, Rabelink TJ, Hansen BC, Clark A, et al: Loss of $\beta$-cell identity occurs in type 2 diabetes and is associated with islet amyloid deposits. Diabetes 64: 2928-2938, 2015.

7. Rhodes CJ: Type 2 diabetes-a matter of beta-cell life and death? Science 307: 380-384, 2005.

8. Bouwens L and Rooman I: Regulation of pancreatic beta-cell mass. Physiol Rev 85: 1255-1270, 2005.

9. McKinnon C and Docherty K: Pancreatic duodenal homeobox-1, PDX-1, a major regulator of beta cell identity and function. Diabetologia 44: 1203-1214, 2001.

10. Porat S, Weinberg-Corem N, Tornovsky-Babaey $S$, Schyr-Ben-Haroush R, Hija A, Stolovich-Rain M, Dadon D, Granot Z, Ben-Hur V, White P, et al: Control of pancreatic $\beta$ cell regeneration by glucose metabolism. Cell Metab 13: 440-449, 2011.

11. Muruganathan U, Srinivasan $\mathrm{S}$ and Vinothkumar V: Antidiabetogenic efficiency of menthol, improves glucose homeostasis and attenuates pancreatic $\beta$-cell apoptosis in streptozotocin-nicotinamide induced experimental rats through ameliorating glucose metabolic enzymes. Biomed Pharmacother 92: 229-239, 2017.

12. Pukel C, Baquerizo $\mathrm{H}$ and Rabinovitch A: Destruction of rat islet cell monolayers by cytokines: Synergistic interactions of interferon- $\gamma$, tumor necrosis factor, lymphotoxin, and interleukin 1. Diabetes 37: 133-136, 1988.

13. Campbell IL, Kay T, Oxbrow L and Harrison L: Essential role for interferon-gamma and interleukin-6 in autoimmune insulin-dependent diabetes in NOD/Wehi mice. J Clin Invest 87: 739-742, 1991.

14. Gurzov EN and Eizirik DL: Bcl-2 proteins in diabetes: Mitochondrial pathways of $\beta$-cell death and dysfunction. Trends Cell Biol 21: 424-431, 2011.

15. Czabotar PE, Lessene G, Strasser A and Adams JM: Control of apoptosis by the BCL-2 protein family: Implications for physiology and therapy. Nat Rev Mol Cell Biol 15: 49-63, 2014.

16. Taniguchi S, Kang L, Kimura T and Niki I: Hydrogen sulphide protects mouse pancreatic beta-cells from cell death induced by oxidative stress, but not by endoplasmic reticulum stress. Br J Pharmacol 162: 1171-1178, 2011.

17. Lenzen S: The mechanisms of alloxan- and streptozotocininduced diabetes. Diabetologia 51: 216-226, 2008.

18. Green AD, Vasu S and Flatt PR: Functionality and antidiabetic utility of $\beta$-and L-cell containing pseudoislets. Exp Cell Res 344: 201-209, 2016.

19. Zhang B, Lu Y, Campbell-Thompson M, Spencer T, Wasserfall C, Atkinson $\mathrm{M}$ and Song S: Alpha1-antitrypsin protects beta-cells from apoptosis. Diabetes 56: 1316-1323, 2007.

20. Zhao Y, Zhang X, Chen J, Lin C, Shao R, Yan C and Chen C: Hexarelin protects rodent pancreatic $\beta$-cells function from cytotoxic effects of streptozotocin involving mitochondrial signalling pathways in vivo and in vitro. PLoS One 11: e0149730, 2016.

21. Elango B, Dornadula S, Paulmurugan R and Ramkumar KM: Pterostilbene ameliorates streptozotocin-induced diabetes through enhancing antioxidant signaling pathways mediated by Nrf2. Chem Res Toxicol 29: 47-57, 2016.

22. Rhee SG and Woo HA: Multiple functions of peroxiredoxins: Peroxidases, sensors and regulators of the intracellular messenger $\mathrm{H}_{2} \mathrm{O}_{2}$, and protein chaperones. Antioxid Redox Signal 15: 781-794, 2011.

23. Tang Z, Xia N, Yuan X, Zhu X, Xu G, Cui S, Zhang T, Zhang W, Zhao Y, Wang S and Shi B: PRDX1 is involved in palmitate induced insulin resistance via regulating the activity of p38MAPK in HepG2 cells. Biochem Biophys Res Commun 465: 670-677, 2015.

24. Bast A, Wolf G, Oberbäumer I and Walther R: Oxidative and nitrosative stress induces peroxiredoxins in pancreatic beta cells. Diabetologia 45: 867-876, 2002.

25. Al-Masri AA, El Eter E, Tayel S and Zamil H: Differential associations of circulating peroxiredoxins levels with indicators of glycemic control in type 2 diabetes mellitus. Eur Rev Med Pharmacol Sci 18: 710-716, 2014.

26. Lee YJ, Song DS, Yoo JS, Hyung KE, Lee MJ, Moon YH, Lee IH, Go BS, Park SY and Hwang KW: Protective functions of peroxiredoxin-1 against cytokine-induced MIN6 pancreatic $\beta$-cell line death. Can J Physiol Pharmacol 91: 1037-1043, 2013. 
27. Song G, Ouyang G and Bao S: The activation of Akt/PKB signaling pathway and cell survival. J Cell Mol Med 9: 59-71, 2005.

28. Pathak S, Dorfmueller HC, Borodkin VS and van Aalten DMF: Chemical dissection of the link between streptozotocin, O-GlcNAc, and pancreatic cell death. Chem Biol 15: 799-807, 2008.

29. Srinivasan K, Viswanad B, Asrat L, Kaul CL and Ramarao P: Combination of high-fat diet-fed and low-dose streptozotocin-treated rat: A model for type 2 diabetes and pharmacological screening. Pharmacol Res 52: 313-320, 2005.

30. Mossahebi M, Quan M, Zhang JS and Li X: FGF Signaling pathway: A key regulator of stem cell pluripotency. Front Cell Dev Biol 8: 79, 2020.

31. Turner NC, Strauss SJ, Sarker D, Gillmore R, Kirkwood A, Hackshaw A, Papadopoulou A, Bell J, Kayani I, Toumpanakis C, et al: Chemotherapy with 5-fluorouracil, cisplatin and streptozocin for neuroendocrine tumours. Br J Cancer 102: 1106-1112, 2010.

32. Deeds MC, Anderson JM, Armstrong AS, Gastineau DA, Hiddinga HJ, Jahangir A, Eberhardt NL and Kudva YC: Single dose streptozotocin-induced diabetes: Considerations for study design in islet transplantation models. Lab Anim 45: 131-140, 2011.

33. Tonne JM, Sakuma T, Deeds MC, Munoz-Gomez M, Barry MA Kudva YC and Ikeda Y: Global gene expression profiling of pancreatic islets in mice during streptozotocin-induced $\beta$-cell damage and pancreatic Glp-1 gene therapy. Dis Model Mech 6 : $1236-1245,2013$

34. Junod A, Lambert AE, Stauffacher W and Renold AE: Diabetogenic action of streptozotocin: Relationship of dose to metabolic response. J Clin Invest 48: 2129, 1969.

35. Rösen P, Nawroth P, King G, Möller W, Tritschler HJ and Packer L: The role of oxidative stress in the onset and progression of diabetes and its complications: A summary of a Congress Series sponsored byUNESCO-MCBN, the American Diabetes Association and the German Diabetes Society. Diabetes Metab Res Rev 17: 189-212, 2001.

36. Nahdi AMTA, John A and Raza $\mathrm{H}$ : Elucidation of molecular mechanisms of streptozotocin-induced oxidative stress, apoptosis, and mitochondrial dysfunction in Rin-5F pancreatic $\beta$-cells. Oxid Med Cell Longev 2017: 7054272, 2017.

37. Gehrmann W, Elsner M and Lenzen S: Role of metabolically generated reactive oxygen species for lipotoxicity in pancreatic $\beta$-cells. Diabetes Obes Metab 12: 149-158, 2010.

38. Mandrup-Poulsen T: Apoptotic signal transduction pathways in diabetes. Biochem Pharmacol 66: 1433-1440, 2003.

39. Ates O, Cayli SR, Yucel N, Altinoz E, Kocak A, Durak MA, Turkoz Y and Yologlu S: Central nervous system protection by resveratrol in streptozotocin-induced diabetic rats. J Clin Neurosci 14: 256-260, 2007.

40. Rhee SG: Overview on peroxiredoxin. Mol Cells 39: 1-5, 2016.

41. Pacifici F, Arriga R, Sorice GP, Capuani B, Scioli MG, Pastore D, Donadel G, Bellia A, Caratelli S, Coppola A, et al: Peroxiredoxin 6, a novel player in the pathogenesis of diabetes. Diabetes 63: 3210-3220, 2014.
42. Wolf G, Aumann N, Michalska M, Bast A, Sonnemann J, Beck JF, Lendeckel U, Newsholme P and Walther R: Peroxiredoxin III protects pancreatic ss cells from apoptosis. J Endocrinol 207: $163-175,2010$.

43. Zhao F and Wang Q: The protective effect of peroxiredoxin II on oxidative stress induced apoptosis in pancreatic $\beta$-cells. Cell Biosci 2: 22, 2012.

44. Maris M, Waelkens E, Cnop M, D'Hertog W, Cunha DA, Korf H, Koike T, Overbergh L and Mathieu C: Oleate-induced beta cell dysfunction and apoptosis: A proteomic approach to glucolipotoxicity by an unsaturated fatty acid. J Proteome Res 10: 3372-3385, 2011

45. Maris M, Robert S, Waelkens E, Derua R, Hernangomez MH, D'Hertog W, Cnop M, Mathieu C and Overbergh L: Role of the saturated nonesterified fatty acid palmitate in beta cell dysfunction. J Proteome Res 12: 347-362, 2013.

46. Elghazi L, Balcazar N and Bernal-Mizrachi E: Emerging role of protein kinase B/Akt signaling in pancreatic beta-cell mass and function. Int J Biochem Cell Biol 38: 157-163, 2006.

47. Franke TF: PI3K/Akt: Getting it right matters. Oncogene 27 6473-6488, 2008.

48. Sarbassov DD, Guertin DA, Ali SM and Sabatini DM: Phosphorylation and regulation of Akt/PKB by the rictor-mTOR complex. Science 307: 1098-1101, 2005.

49. Cho H, Mu J, Kim JK, Chu Q, Crenshaw EB III, Kaestner KH, Bartolomei MS, Shulman GI and Birnbaum MJ: Insulin resistance and a diabetes mellitus-like syndrome in mice lacking the protein kinase Akt2 (PKB beta). Science 292: 1728-1731, 2001.

50. Dan HC, Sun M, Kaneko S, Feldman RI, Nicosia SV, Wang HG, Tsang BK and Cheng JQ: Akt phosphorylation and stabilization of X-linked inhibitor of apoptosis protein (XIAP). J Biol Chem 279: 5405-5412, 2004.

51. Huo X, Liu S, Shao T, Hua H, Kong Q, Wang J, Luo T and Jiang Y: GSK3 protein positively regulates type I insulin-like growth factor receptor through forkhead transcription factors FOXO1/3/4. J Biol Chem 289: 24759-24770, 2014.

52. Li Y, Hansotia T, Yusta B, Ris F, Halban PA and Drucker DJ: Glucagon-like peptide-1 receptor signaling modulates $\beta$ cell apoptosis. J Biol Chem 278: 471-478, 2003.

53. Mishra R: Glycogen synthase kinase 3 beta: $\mathrm{Can}$ it be a target for oral cancer. Mol Cancer 9: 144, 2010.

54. Parida S, Pal I, Parekh A, Thakur B, Bharti R, Das S and Mandal M: GW627368X inhibits proliferation and induces apoptosis in cervical cancer by interfering with EP4/EGFR interactive signaling. Cell Death Dis 7: e2154, 2016.

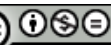

This work is licensed under a Creative Commons Attribution-NonCommercial-NoDerivatives 4.0 International (CC BY-NC-ND 4.0) License. 